belts, pipes, and also the arrangements not directly required for experimental work, thus leaving the floor clear from obstruction. Beneath the lower floor a tank of ten thousand gallons capacity has been built, A wide range of machinery has been installed. The department also comprises a machine shop and a pattern shop.

In the lecture rooms and laboratories of the department of physics and electrical engineering the machinery is of the latest type. Everything has been provided for giving a complete training, theoretical and practical, to the students.

As is to be expected in a city like Belfast, particular attention has been paid to the equipment of the department of textile manufactures, and the result has been to make the new institute almost unique in this respect. Particular emphasis has naturally been laid on the various facts and statistical data, and a historical retrospect of technical instruction in Belfast, whilst the book is finely illustrated with internal and external views of the institute. The book is to be sold at $1 s$., or by post Is. $3 d$. Copies can be obtained on application to the institute.

\section{LONDON DAY TRAINING COLLEGE FOR TEACHERS.}

I $\mathrm{N}$ June, I901, in response to urgent representations from the School Board for London and other important bodies, the late Technical Education Board of the London County Council secured the adoption of a scheme under which the Council undertook to provide and maintain a day training college for men and women

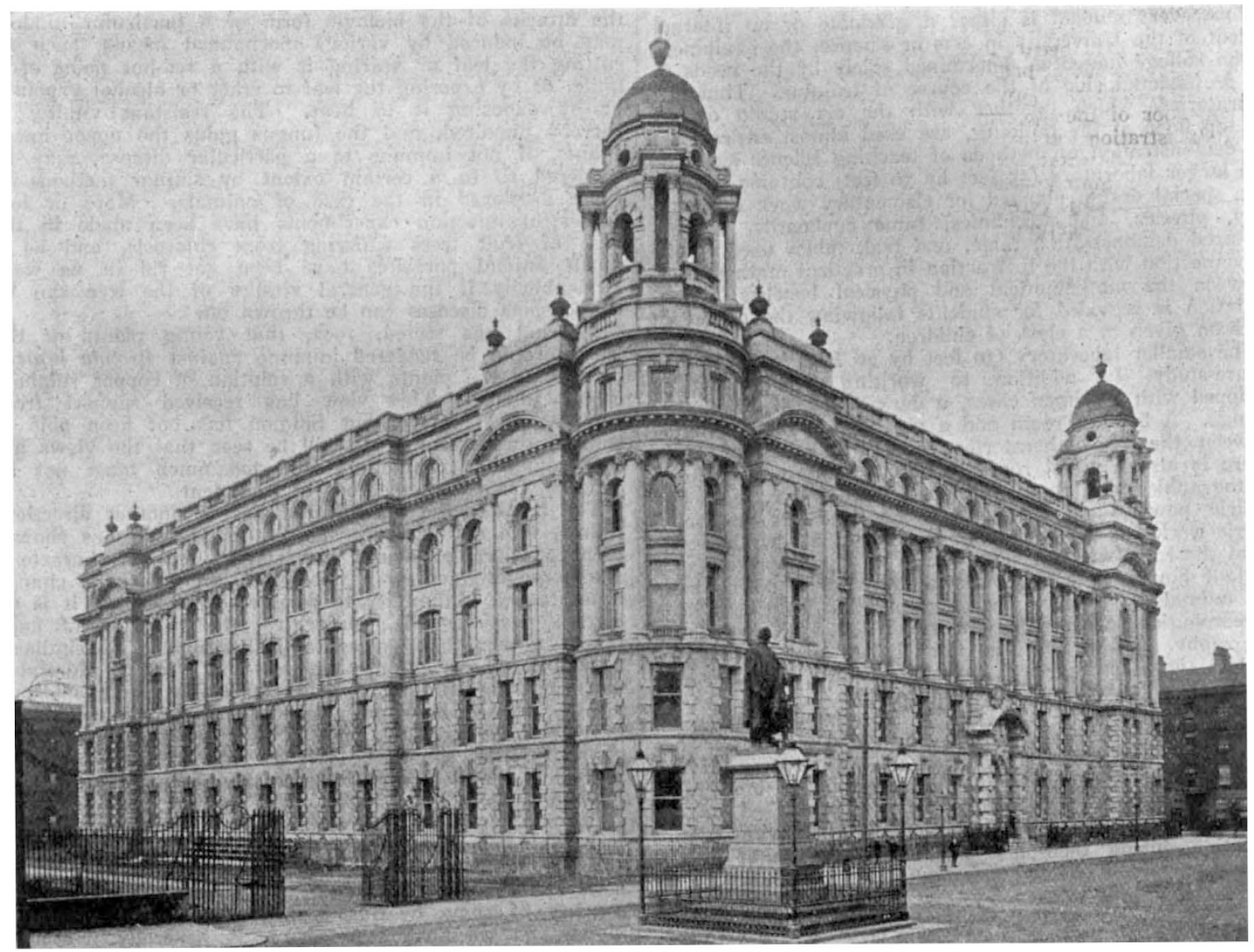

The Municipal Technical Institute, Belfast.

flax products, and in this connection a very complete range of machines has been installed.

It is unnecessary to examine in detail the equipment of the remaining departments. In every case the expenditure has been equally generous, and the results equally satisfactory. Special mention may be made of the art school, which occupies the entire top storey, and now ranks as one of the best schools in the kingdom. The chemical laboratory is the largest room in the institute, and has been furnished on a complete scale.

Belfast may well be proud of its new institute. Facilities are now provided for the carrying on of the work of technical education such as cannot fail in the immediate future to have an important and beneficial influence on its trade and industries.

In connection with the opening ceremony, a "Souvenir" book has been issued. This contains a number of portraits, views of the institute, a chronological table, salient teachers in close connection with the newly re-constructed University of London, and a chair of education in the University to be held by the principal of the college.

Work was commenced in October, 1902, under the direction of Prof. John Adams, and has been continued in various temporary premises until the present term, when the college entered into possession of the southern half of the fine block of buildings designed by the Council's architect (Mr. W. E. Riley) to fill a site recently cleared at the Holborn end of Southampton Row. (The northern half of this block will, when finished, be occupied by the L.C.C. Central School of Arts and Crafts.) The celebration of the entrance of the college into its permanent home was the motive of an interesting ceremony conducted by the chairman of the Council (Mr. Percy Harris) on Saturday last, when Lord Rosebery, as Chancellor of the University, formally declared the building open.

The majority of the students of the college are " recogNO. I 984 , VOL. 77$]$ 
nised students" (formerly "King's scholars"), receiving a grant from the Board of Education, who have matriculated, and are thus qualified to enter one of the schools of the University for a three years' course, leading up to the degree in arts or science. Concurrently with their academic studies they take a course of professional instruction at the training college with a view to certification by the Board. In addition to these students, there is a smaller number of graduates who take a one year's course in preparation for the University's diploma in pedagogy, and intend to teach in secondary schools. Since, however, a rapidly increasing proportion of the recognised students enter with a higher qualification than matriculation, and obtain the degree before the conclusion of the three years' course, the work of the college will in a few years become very largely post-graduate, and may be expected to have an important influence upon the standard of teaching in the elementary schools of London.

Since every student is either a graduate or an internal student of the University in arts or science, the equipment of the college has been determined solely by the needs of the professional side of the course of training. Thus the laboratories, which together with the art studio occupy the top floon of the building, are used almost entirely for the demonstration of methods of teaching science subjects. The larger laboratory ( 55 feet by 30 feet) contains benches of a special design planned for elementary work in chemistry, physics, and mechanics, fume cupboards, a wellequipped demonstration table, and teak tables used chiefiy in connection with the instruction in practical mathematics. Between the mathematical and physical benches accommodation is provided for students following the course of a lesson given to a class of children.

The smaller laboratory ( 30 feet by 20 feet) is devoted to nature-study. In addition to working benches, it is equipped with specimen cases, a dark cupboard, and other fittings. A balance room and a preparation room situated between the two aboratories serve the needs of both. There is also a small room (readily transformable into a photographic dark room) equipped with water, gas, and electric power, and intended to be used for anthropometric work and for researches in pedagogical psychology.

On the roof, within easy access from the laboratories, is a plant house containing a large tank for aquatic plants and animals. The level space around this is utilised as a meteorological observatory in connection with lessons in geography. Finally, on the floor below that already described, is a pedagogical museum, which performs the functions of a geographical laboratory.

Carefully planned and closely correlated courses in mathematics, geography, nature-study, and physical science are taught in these laboratories to the children of the demonstration schools by students under supervision. Most of these students either have already graduated or are about to sit for the B.Sc. degree, and are paying special attention during their last year to the teaching of the scientific subjects of the curriculum.

\section{IMMUNITY TO DISEASE AMONG PLANTS.}

THE question of immunity to disease has been so closely studied and so frequently discussed in connection with the diseases of man that it seemed to me that it might be of interest to bring together some of the facts now known to us about the incidence of disease among plants and the theories which have been advanced as to the cause of the immunity which some species and varieties exhibit to various diseases.

The late Prof. Marshall Ward has shown that Puccinia dispersa, the brown rust of grasses, seems to exist in several "biologic forms," each of which attacks only one group of nearly related species of Bromus, and the same condition obtains in the Erisipheæ, or mildews, according to Salmon. How is it that these fungi are incapable of infecting such nearly related host plants as are represented by the species within a single genus? The suggestion was originally made that differences in the thickness of the cell walls, fewer or smaller stomata, 1 Abridgerd from an address delivered at the annual meeting of the British
Pharmaceutical Conference at Manchester by Prof. F. E. Weiss.

NO. I984, VOL. 77$]$ longer hairs, \&c., were the obstacles which repelled the fungi and rendered certain species and genera of plants immune to the attacks of particular fungi. Working with the different species of Brome, Marshall Ward was, however, able to show that there was no relationship between the stomata, hairs, and so forth, and the infectibility of the species. Immunity did not in any way depend upon the anatomical characters of the host plant, but entirely on physiological reactions of the protoplasm of the fungus and of the cells of the host. In other words, infection and resistance to infection depend on the power of the fungus protoplasm to overcome the resistance of the cells of the host by means of enzymes or toxins, and reciprocally on the protoplasm of the cells of the host to form anti-bodies which destroy such enzymes or toxins, just as is the case with resistance of animal organisms to their bacterial foes. Salmon has shown in his experiments that susceptibility in a leaf normally immune to the attacks of the biologic form of a particular mildew may be induced by various mechanical means, such as cutting the leaf or searing it with a red-hot point of a $\mathrm{knife}$, or by exposing the leaf to ether or alcohol vapours, or by exposing it to heat. The resistant vitality is thereby impaired, and the fungus gains the upper hand. Plants, if not immune to a particular disease, may be rendered so to a certain extent by similar methods to those employed in the case of animals. More or less successful injection experiments have been made in the case of fruit trees suffering from chlorosis, and as a result animal parasites have been got rid of as well. Undoubtedly if the general vitality of the tree can be raised some diseases can be thrown off.

Marchal has stated, 1902, that young plants of the lettuce could be rendered immune against Bremia latucae by feeding the plants with a solution of copper sulphate ( $x$ in 30,000 ). This view has received support from Laurent and Massée, but Salmon has not been able to confirm these results. It will be seen that the views are still somewhat conflicting, and too much must not be expected from such methods of treatment.

The hope of the agriculturist lies in another direction. Plants, like animals, are subject, as Darwin has shown, to a considerable amount of variation, and all characters, whether anatomical or physiological, are subject to change or mutation. Immunity to disease, dependent as it is on certain physiological peculiarities, the secretion of antitoxins, rather than on anatomical structure, is similarly a subject of variation. We see this readily illustrated when passing through a field exposed to some epidemic disease, where here and there plants are found which have been either only slightly damaged or not attacked at all. These should be selected for breeding purposes, and thus hardier varieties can be produced. Another method which has shown itself useful for producing resistant forms is by hybridising. It is a well-known fact that hybrids, while partaking of the nature of one or both of the parents in most characters, generally exceed both in vegetative vigour-a characteristic to which the sterility of some hybrids is attributed. But vegetative vigour, as we have seen above, is generally associated with immunity to disease, and hence hybrids are often found to be more resistant. This is not always the case, for in this respect hvbrids vary too, but the French horticulturists MM. Bouttes and Guillon have been successful in producing hybrid vines which are more resistant to the mildew than either of the parents.

In the selection of immune varieties one is faced with the unfortunate fact that many of the most resistant forms are the least valuable, producing poorer fruits and seeds than the delicate forms. But by judicious hybridising this defect of the immune race can be largely counteracted. Mr. Lewton Brain has collected a good deal of information on this point. Both in the case of vines and in wheat many disease-resisting forms have been produced.

In connection with cotton crops, it is remarkable how great is the range of variation with regard to the resistance of the plants to the wilt disease (Neocosmospora vasinfecta). By selection and suitable hybridising, Rivers has been able to obtain varieties which remained untouched by the disease, while of the neighbouring crops 